\title{
Elaborating Indigenous Science Content into Science Learning Process: A New Science Instructional Model to Develop Students' Local Wisdom-Based Characters and Higher Order Thinking Skills
}

\author{
I Wayan Suastra ${ }^{1 *}$, Ni Ketut Rapi ${ }^{2}$, Putu Yasa ${ }^{3}$ and I Gede Arjana \\ 1,2,3,4 Physics Education Study Program, Universitas Pendidikan Ganesha. Singaraja, Indonesia \\ *e-mail: iwsuastra@undiksha.ac.id
}

\begin{abstract}
Character building becomes an essential part in the science learning process to prepare the students as the next generations of our nations. This study aims to develop a valid, practical, and effective learning model combined with indigenous science content for junior high school students in developing local wisdom-based characters and high-order thinking skills. This research is a a research and development $(R \& D)$ approach with the Borg and Gall model involving 36 junior high school science teachers (72 teachers). The research instrument were a character questionnaire as well as a test of problem-solving, critical and creative thinking tests, along with an assessment rubric to measure the depth of students' cognitive abilities. From the results of the learning model trial, it was found that there are eight characters based on Balinese local wisdom that can be developed in science learning for junior high school students namely religious, being honest (satyam), tolerance (tat twam asi), responsible (sesana/swadharma), curious, jengah, hardworking and generous, caring and friendly with nature. Conceptually, the core stages of the junior high school science learning model to develop Balinese local wisdom based characters include: initial exploration, investigation from various perspectives, elaboration, and confirmation and reinforcement. The stages in the science learning model that develop characters based on local wisdom provide opportunities for teachers to improve students' cognitive abilities, especially in the realm of higher-order thinking skills.
\end{abstract}

Keywords: Indigenous Science, Local Wisdom-Based Characters, High-Order Thinking Skills

\section{Introduction}

One of the most crucial problems that has so far plagued the education system of Indonesia is the weakening of students' character. There are several cases happening among teenagers in junior high schools that reflects the degeneration of students' moral and characters such as: student fights, bullying at school, drug use, the spread of hoaxes, radicals, intolerance, lack of critical thinking skills, laziness to study, and lack of ethics / manners. These problems show that the character education has not been properly actualized in schools. This also indicates the failure to develop moral and value education in schools (Aisah, 2014; Suastra et al., 2017). Furthermore, the values of local wisdom that exist in the community do not get enough attention in the learning process in schools, even though these values are still very relevant to be applied in social life and can maintain the integrity of the Indonesian nation (Suastra, 2011). The lack of student morale which results in low students' character is an indicator of failure in integrating knowledge of values into positive action (Abu et al., 2015; Aisah, 2014; Lickona, 1999; Lopes et al., 2013).

Another problem in Indonesia's education system is a non-optimal implementation of science and mathematics learning methods in facilitating students to develop their higher order thinking skills. Several studies showed that students' higher order thinking skills in Indonesia are in a poor condition (Agustihana \& Suparno, 2018; Antara et al., 2020; Zulfiani et al., 2020). The results of study from TIMSS and PISA for higher-order thinking skills category such as creative, critical, and problem-solving thinking also always showed that Indonesia is ranked at the bottom among of the surveyed countries (Andrews et al., 2014; Marhaeni et al., 2018). The results of the 2015 Program for International Student

\footnotetext{
${ }^{*}$ Corresponding author.
}

Received January 15, 2021; Accepted April 10, 2021; Available online September 25, 2021

Copyright $@ 2021$ by Author. Published by Universitas Pendidikan Ganesha. 
Assessment (PISA) show that the reading literacy skills of Indonesian students is ranked 57, mathematics literacy is ranked 61 , and scientific literacy is ranked 60 out of 65 countries (Odell et al., 2021). The results of the Trend International Mathematics Science (TIMSS) survey in 2007 reported that Indonesia was ranked 36 out of 49 countries in the world for the category of average science scores in the cognitive domain which is an important aspect of problem-solving abilities (Mullis et al., 2016). Indonesia gets a knowing score of 425 , applying score of 426 , and reasoning score of 438 , all of which are still below the TIMSS average score of 500 . This points out that Indonesian students' ability in high order thinking (HOT) is still low because the questions in PISA and TIMSS require higher-order thinking skills. Character building has been proclaimed since Indonesia's independence by the nation's founding fathers, the first president of the Republic of Indonesia, Bung Karno. Bung Karno emphasized that this nation must be built with prioritizing character development because this is what makes Indonesia a great, advanced and victorious, and dignified nation. If character building is not carried out, this nation will become a nation of coolies. Thus, the character building is a very important and urgent matter (Koesoema, 2009; Samani \& Hariyanto, 2012). Therefore, this research is very relevant to be carried out in elementary and junior high schools because it is the foundation for further character development.

Indigenous science or often called ethno science is a system of knowledge that is owned by a nation or more precisely an ethnic group that is passed down from one generation to the next which is used in solving the problems of their daily life (Suastra, 2005). However, in reality, ethno science has received less attention in the context of learning in schools. This is in accordance with the results of study which states that the low quality of science education in Indonesia is due to the lack of attention to students' local culture including the indigenous science (Suastra, 2005). In their daily lives, students always face and intersect with their culture and indigenous science. The integration of local wisdom into learning process can that utilizes the student's environment and its surrounding as a learning target, learning resource, and learning tool (Febriani et al., 2019). The same thing was stated by previous study who stated that cultural background has significant effect on students' way of knowing and learning science (Baker, 1995). Students 'emotionally laden and culturally framed life-world knowledge subsumes interpretations of new experiences and determines the development of personal constructs of meaning. The knowledge of the child's culture and learning styles helps teachers examine their own instructional practices and become sensitive to providing diverse learning experiences (Mantiri, 2013). Apart from that, implementing learning process based on local wisdom can increase scientific literacy, student's' critical thinking, and problem-solving skills (Kristanto et al., 2019; Putri \& Aznam, 2019; Setiawan et al., 2017).

Local wisdom is defined as truth that has traditionally been established in an area (Suastra, 2017; Sudarmiani, 2013). Local wisdom can also be understood as a human effort by using reasoning (cognition) ability to act and behave towards something, object, or event that occurs in a certain space. Etymologically, wisdom means a person's ability to use his or her mind to respond to an event, object or situation, while local shows the interaction space where the event or situation occurs. Thus, local wisdom is substantially a norm that applies in a society whose truth is believed and becomes a reference in daily actions and behavior. Therefore, local wisdom is an entity that largely determines human dignity in the community (Geertz, 1992). One of the Balinese local wisdom in the context of learning (student-teacher) stated in the Brahmacari level is aguron-guron or Asewaka Guru para Acarya (teachers educate their students) by providing spiritual instructions, virtue, charity, devotion, all of which are called Dharma. This study aims to develop a valid, practical, and effective learning model combined with indigenous science content for junior high school students in developing local wisdom-based characters and high-order thinking skills

\section{Method}

This study is a multi-year applied research (2020-2021) which aims to produce a valid, practical, and effective science learning model. The study used a research and 
development (R \& D) approach by adapting Borg and Gall model (Borg \& Gall, 1983; Sugiyono, 2014). In the first year (2020), a need analysis of new learning model was carried out which involved 72 science teachers who teach in 36 junior high school in Bali. The research activities were focused on analyzing the needs of developing a conceptual science learning model elaborated with indigenous science content. In the second year (2021), a learning model development, the preliminary testing and evaluation of learning model design will be conducted. The preliminary testing involved 9 schools ( 3 junior high schools in the rural area, 3 junior high schools in between the rural and urban area, and 3 junior high schools in the urban area) spread across Bali. In 2021, as the last year this research will be carried out an extensive learning model testing involving 36 junior high schools (72 junior high school science teachers) in Bali.

The independent variable in this study is the science learning model with indigenous science content and conventional learning models, while the dependent variable is the character based on local wisdom, students' high-level thinking abilities (critical thinking, creative thinking, and problem solving). The research instrument was a character questionnaire, a problem-solving ability test, critical thinking, a creative thinking test, along with an assessment rubric. The test of problem solving, critical thinking, and creativity is tested for validity and reliability, with minimal validity and high reliability. The data obtained were then analyzed descriptively.

\section{Result and Discussion}

\section{Results}

The results of the needs analysis of local wisdom-based characters that can be developed in junior high school science learning elaborated with indigenous science content include: religious, being honest (satyam), tolerance (tat twam asi), responsible (sesana / swadharma), curious, jengah, hardworking and generous, caring and friendly with nature and its indicators are as shown in Table 1.

Table 1. Result of Analysis of National Character Based on Balinese Local Wisdom

\begin{tabular}{|c|c|c|c|}
\hline No & Character aspects & Indicators & Mean \\
\hline \multirow[t]{2}{*}{1} & $\begin{array}{l}\text { RELIGIOUS } \\
\text { Attitudes and behaviors that } \\
\text { are obedient in carrying out the }\end{array}$ & $\begin{array}{l}\text { Admire the greatness of God for } \\
\text { natural phenomena that are amazing } \\
\text { and hidden }\end{array}$ & 4,20 \\
\hline & teachings of their religion & $\begin{array}{l}\text { Feel the greatness of God through the } \\
\text { diversity that exists in the world }\end{array}$ & 4,10 \\
\hline \multirow[t]{2}{*}{2} & $\begin{array}{l}\text { BEING HONEST } \\
\text { Behavior that unites good }\end{array}$ & $\begin{array}{l}\text { Being honest in doing assignments or } \\
\text { science tests }\end{array}$ & 4,20 \\
\hline & $\begin{array}{l}\text { thoughts, words, and actions } \\
\text { (Tri Kaya Parisudha) }\end{array}$ & $\begin{array}{l}\text { Being open in expressing his learning } \\
\text { difficulties to both friends and teachers }\end{array}$ & 4,10 \\
\hline \multirow[t]{2}{*}{3} & $\begin{array}{l}\text { TOLERANCE (TATTWAMASI, } \\
\text { MENYAMA BRAYA) } \\
\text { The attitude of brotherhood }\end{array}$ & $\begin{array}{l}\text { Student does not differentiate ethnicity, } \\
\text { race, religion in carrying out school } \\
\text { assignments }\end{array}$ & 4,50 \\
\hline & $\begin{array}{l}\text { without distinguishing religion, } \\
\text { ethnicity, socio-economy, and } \\
\text { gender }\end{array}$ & $\begin{array}{l}\text { Willing to accept a different opinion } \\
\text { from other friends }\end{array}$ & 4,25 \\
\hline \multirow[t]{3}{*}{4} & $\begin{array}{l}\text { RESPONSIBLE (SESANA } \\
\text { ATAU SWADHARMA) }\end{array}$ & $\begin{array}{l}\text { Do the assignments carefully and } \\
\text { neatly and collect them on time }\end{array}$ & 4,20 \\
\hline & $\begin{array}{l}\text { A sense and attitude of } \\
\text { responsibility towards duties } \\
\text { and responsibility }\end{array}$ & $\begin{array}{l}\text { Use time effectively to complete } \\
\text { assignments in class and outside of } \\
\text { class }\end{array}$ & 4,20 \\
\hline & & $\begin{array}{l}\text { Always try to find information about the } \\
\text { subject material from various sources }\end{array}$ & 4,00 \\
\hline 5. & CURIOUS (SEKADI & Always read books on science, & 4,25 \\
\hline
\end{tabular}




\begin{tabular}{|c|c|c|c|}
\hline No & Character aspects & Indicators & Mean \\
\hline & NYAMPAT (MENYAPU), & technology, and culture & \\
\hline & HILANG LUHU BUKE KATAH) & Always wanted to try to carry out & 4,20 \\
\hline & $\begin{array}{l}\text { Ask, discuss, and want to } \\
\text { investigate/ }\end{array}$ & $\begin{array}{l}\text { investigations over natural phenomena } \\
\text { which is related to science lessons }\end{array}$ & \\
\hline & $\begin{array}{l}\text { know various phenomenon that } \\
\text { exist in nature }\end{array}$ & $\begin{array}{l}\text { Always want to find out other } \\
\text { (alternatives) answers to solved } \\
\text { science problems }\end{array}$ & 4,00 \\
\hline \multirow[t]{2}{*}{6} & $\begin{array}{l}\text { JENGAH } \\
\text { Feel embarrassed if they fail or } \\
\text { cannot complete their duties }\end{array}$ & $\begin{array}{l}\text { Feeling embarrassed when student } \\
\text { can't complete the assignments given } \\
\text { by the teacher }\end{array}$ & 4,50 \\
\hline & & $\begin{array}{l}\text { Feeling ashamed of being caught } \\
\text { cheating in a science test/ exam }\end{array}$ & 4,30 \\
\hline \multirow[t]{4}{*}{7} & $\begin{array}{l}\text { HARDWORKING AND } \\
\text { GENEROUS }\end{array}$ & $\begin{array}{l}\text { Diligently follow the lesson to get } \\
\text { satisfying results }\end{array}$ & 4,40 \\
\hline & $\begin{array}{l}\text { Doing work until you get } \\
\text { satisfying and beneficial results } \\
\text { for yourself and others }\end{array}$ & & \\
\hline & Atharwaveda XX.18.3 & & \\
\hline & & Loves to help friends who need help & 4,20 \\
\hline \multirow[t]{2}{*}{8} & $\begin{array}{l}\text { CARE AND FRIENDLY WITH } \\
\text { NATURE (SEKADI MANIK } \\
\text { RING CACUPU) }\end{array}$ & $\begin{array}{l}\text { Planning and implementing various } \\
\text { activities to prevent environmental } \\
\text { damage }\end{array}$ & 4,50 \\
\hline & $\begin{array}{l}\text { Attitudes and actions that } \\
\text { always seek to protect and } \\
\text { preserve the natural } \\
\text { environment around them } \\
\text { Atharwaveda IX.10.12 }\end{array}$ & $\begin{array}{l}\text { Able to make the right decisions in } \\
\text { preventing or overcoming } \\
\text { environmental damage }\end{array}$ & 4,10 \\
\hline
\end{tabular}

\section{Discussion}

Based on the results of data analysis, it was found that the methods that could be developed for science learning were inquiry / investigation (mean 4.75), discussion / question and answer (mean 4.63), and demonstration (mean 4.38). The most suitable method for its development is the inquiry / inquiry method. The stages of science learning to develop character based on local wisdom which based on the iquiry method include: (a) exploration of students' initial knowledge, (b) inquiry/investigation from various perspectives (scientific, socio-cultural, historical), (d) elaboration, and (e) confirmation and reinforcement. In addition to developing character based on local culture, science learning with original science can also be implemented later to help improve students' cognitive abilities, especially in the realm of higher-order thinking skills. From the results of data analysis in the need analysis process, it was also found that the average percentage of student success in answering science highorder questions was $53 \%$ in the C4 category (ability to analyse), $40 \%$ in the C5 category (ability to evaluate), and $28 \%$ in the $\mathrm{C} 6$ category (creative ability). These results indicate that students' high-order thinking skills, especially in science learning, are still low.

The aspects of character based on Balinese local wisdom presented in table 1 are extracted from people's attitudes and behaviour in everyday life inspired by Hindu scriptures such as Begawad gita, Regveda, Atharwa veda, Silakramaning Aguron-guron, and Tri Kaya Parisudha. Another source is also obtained from the philosophy that develops in Balinese society, namely Tri Hita Karana, which advocates three harmonies in human life, namely harmony between humans and God (religious), harmony between humans and other human 
beings, and harmony between humans and butha/the universe. Suja (2000: 56-57) stated that the human relationship (Prajah) with God (Prajapati) is based on the concept of Kawula Gusti, in the sense that God is Gusti (ruler), while humans are God's servants with sincere devotion. Human relationship with each other are based on the Tat Twam Asi concept, which teaches that all human being are the same. We are all (without being restricted by any label) are brothers, va suduiva kutum bhakam. As human beings, we must love each other, respect each other and serve each other. "treat others the way you want to be treated". The harmony of the human relationship with nature takes the parable "kadi manic ring cecupu". Humans are likened to manik (fetus), while nature is a cecupu (womb). This concept implies that humans must live surrounded by nature, and it is from nature that humans get food or the means to live. In this position it is clear that humans live freely in the attachment to nature. Humans are free to take anything from nature, but they are obliged to preserve it. If nature is corrupted, then humans will definitely be destroyed. On that basis, humans should respect and protect nature. The sacred Vedic literature states, "This earth is our mother, we are her sons (Atharwaveda, XII: 1.12), and" Earth is mother, and heaven is our father (Yayurveda XXV: 17). All these local wisdom-based characters are basically inspired from the natural view of Balinese people. Spirituality is contained in the elements of the cosmos (bhuwana agung / macrocosm) and humans as microcosmic elements (buana alit) and humans are responsible for maintaining harmonious relationships with God, humans, and nature (Suastra, 2017).

Other findings, such as the character of "jengah (feeling embarrassed when not being able to successfully complete something well) are everyday words that parents order when doing a job. The task given to us should be done seriously and responsibly so that it does not cause embarrassment for our own selves, our family and society. Curiosity, taken from the lyrics of Balinese song as a message from the elders (father, mother, grandmother, grandfather) to their children and grandchildren, "de ngaden awak bisa depang anake ngadanin, geginane open nyampat, ilang luhu buke katah, wiadin ririh enu liu pelajahan". The meaning of the lyrics is that we should not be so arrogant if we can do something, it's just like sweeping, we clean up the trash but the dust will come again. Even if we think that we are smart, there is still a lot to be learned because the knowledge is endless. We shouldn't be quick to be satisfied with the knowledge we have. Thus, the main message is actually lifelong learning.

Based on the results of data analysis, it was also found that the the most suitable method for developing character based on local wisdom is the inquiry / inquiry method. The inquiry method is the most appropriate method in developing science process skills, creativity, critical thinking, and scientific attitudes or scientific characters (Alpusari \& Putra, 2015; Dwianto, A et al., 2017; Hairida, 2016; Harlen, 1992; Medwell et al., 2009; Neka, I et al., 2015; Neuby, 2010; Priyantini et al., 2015; Suastra, 2011; Sumaji, 1998; Wenning, 2005). Thus, science learning does not only focus on the dimensions of concepts, processes, and applications, but has expanded the dimensions of science education, namely positive attitudes, creativity, and the nature of science itself (Enger \& Yager, 2000); namely science as a product (Van Manen, 2016), science as a process (Van Joolingen et al., 2005), and science as values (Ismail et al., 2013; Loke \& Chow, 2007).

Starting the lesson, students pray together according to their respective religions and beliefs so that they are given safety and fluency in learning. This is done to increase students' awareness of the greatness of God and to give thanks for his creation. Thus, it will foster confidence in the existence of God who created this world with various natural phenomena that hold mystery (spiritual character). Stage 1, initial exploration, students are invited to make observations, show videos or pictures of strange / amazing natural phenomena (discrepant event). This will raise their curiosity about the phenomenon that occurs, giving rise to the question of what, why and how it happened. In addition to displaying videos or learning media about natural phenomena that are close to students' lives, teachers can also provide a strong perception through the delivery of aspects of original science that are contained in local culture that can be found in everyday student life such as folklore, culture and local traditions. or the arts that exist in the local community. The 
second stage, investigations from various perspectives, namely students are invited to carry out scientific investigations and investigations from other perspectives, such as history, language, and other local cultures. At this stage, various of locam wisdom-based characters such as the character of "jengah" (embarrassment if unable to do or explain), responsible, being honest, and care for the natural environment can be developed.

In the third stage, elaboration allows students to relate the science lessons they learn to the real world. This allows students to develop their reasoning, both inductive and deductive reasoning. As this stage is carried out in heterogeneous groups, it allows interaction between those who differ in socioeconomic, racial, ethnic, and religious terms. The impact of the activities in the elaboration phase is the formation of tolerance, honesty, responsibility, curiosity, the character of "jengah", hardworking, and a sense of concern for the surrounding natural environment. In the last stage, in the confirmation and reinforcement phase, the teacher plays a role in emphasizing the concepts and principles of science (scientific knowledge), as well as introducing and inviting students to internalize the values of good local wisdom (cultural) characters. Finally, in the closing stage, students are again invited to reflect on their learning process, thoughts, words, and actions (Trikaya Parisuda). If there is something wrong, the student must apologize, and if there is something missing then they have to improve it. Therefore, the role of the teacher is very important in the learning process, which is to act as role models and cultural guides who are active, creative, and wise so that students will gain learning experiences that are filled with good values and have responsibility for themselves, others, and towards natural and socio-cultural environment (Aikenhead.G., 2000; Elmubarok, 2008; Suastra, 2010).

In order to also improve students' higher order thinking skills while developing their characters based on local wisdom, teachers must realize that higher order thinking skills can occur when students are able to connect and transform the knowledge they already have with problems or things that have not been taught in learning. Students' thinking abilities at a higher level will be formed through learning processes and activities that can stimulate students to elaborate on the knowledge they get. The improvement of students' higher order thinking skills also depend heavily on developing collective interaction skills, personal development and appropriate communication approaches to reveal persuasive reasons for arguing scientifically (Holbrook \& Rannikmae, 2009). Science learning model with indigenous science content can be an alternative learning model that can facilitate students in developing higher order thinking skills. In the stages of the learning process, students will be invited to elaborate on their initial knowledge by listening to information about the environment, natural phenomena, and elements of local culture that have similarities with the concepts of the scientific knowledge they are learning. This will provide greater opportunities for students to more easily extract the information into their mind's memory because the information conveyed is directly related to the situation and environment which they are familiar with. This is in accordance to the study which found that the environment as a source of learning has many positive impacts on students (Suryanti et al., 2020). It makes them easier to understand the subject, get in touch with actual environmental conditions, and encourage them to take part in maintaining and protecting the environment.

At another stage, students can also be invited to be actively involved in scientific investigations that link the concept of the material with real problems that are still related to the local environment and culture. This stage can continuously stimulate students in connecting their initial knowledge to evaluate, analyze and create problem-solving solutions. In the science learning process elaborated with indigenous science (local culture), an important stage that can also improve students' higher-order thinking skills is the confirmation and reinforcement stage where the teacher can emphasize scientific concepts that are contained in the local culture around students.

\section{Conclusions and Suggestions}

Eight characters based on Balinese local wisdom that can be developed in science learning for junior high school namely religious, being honest (satyam), tolerance (tat twam 
asi), responsible (sesana/swadharma), curious, jengah, hardworking and generous, caring and friendly with nature. These characters are extracted from various reference sources, messages from parents to children or the next generation, as well as the results of discussion from community leaders and teachers who have more than ten years of teaching experience. Conceptually, the core stages of science learning in junior high school to develop Balinese local wisdom-based characters include: initial exploration, investigation from various perspectives, elaboration, confirmation and reinforcement. The teacher's role is very important in the learning process, namely, as role models as well as a cultural guides to develop knowledge of physics, science process skills, and good character of students. It is necessary to do a more search involving the number of responses and a wider area as well as testing the learning model empirically in schools. Further studies are needed to be able to determine the impact of the developed model, especially in developing local wisdom-based characters. For further research, it is necessary to carry out more searches involving the number of responses and a wider area as well as testing the learning model empirically in schools. It is also necessary to carry out further studies to be able to determine the impact of the developed model, especially in developing local wisdom-based characters.

\section{Acknowledgements}

Financial support for this study was provided by a grant from DIPA Undiksha.

\section{References}

Abu, L., Mockhtar, M., Hassan, Z., \& Suhan, S. Z. D. (2015). How to Develop Character Education of Madrassa Students in Indonesia. Journal of Education and Learning, 9(1), 79-86. https://doi.org/10.11591/edulearn.v9i1.768.

Agustihana, S., \& Suparno. (2018). Effectiveness of Physics Mobile Learning Media to Improve Higher Order Thinking Skills of Students in Thermodynamics. Journal of Physics: Conference Series, 1097(1). https://doi.org/10.1088/17426596/1097/1/012031.

Aikenhead.G. (2000). Renegotiating the Culture of School Science. In R. Miller (Ed.), Improving Science Education: The Contribution of Research. USASK. http://www.usask.ca/education/people/aikenhead/renegotiation.htm.

Aisah, A. R. (2014). The Implementation of Character Education Through Contextual Teaching and Learning at Personality Development Unit in The Sriwijaya University Palembang. International Journal of Education and Reserach, 2(10), 203-214. https://www.ijern.com/journal/2014/October-2014/17.pdf.

Alpusari, M., \& Putra, R. A. (2015). The Aplication of Cooperative Learning Think Pair Share (TPS) Model to Increase Process Science Skill in Class IV Elementary School Number 81 Pekanbaru City. International Jornal of Science and Research (IJSR), 4(4), 2805-2808. https://www.ijsr.net/archive/v4i4/SUB153806.pdf.

Andrews, P., Ryve, A., Hemmi, K., \& Sayers, J. (2014). PISA, TIMSS and Finnish mathematics teaching: An enigma in search of an explanation. Educational Studies in Mathematics, 87(1), 7-26. https://doi.org/10.1007/s10649-014-9545-3.

Antara, I. G. W. S., Sudarma, I. K., \& Dibia, I. K. (2020). The Assessment Instrument of Mathematics Learning Outcomes Based on HOTS Toward Two-Dimensional Geometry Topic. Indonesian Journal Of Educational Research and Review, 3(2), 1924. https://doi.org/ijerr.v3i2.25869.g15588.

Baker. (1995). The Effect of Culture on the Learning of Science in non-WesternCountries: The Results of a Integrated Research Review. International Journal Science Education, 17. https://doi.org/10.1080/0950069950170602.

Borg, W. R., \& Gall, M. D. (1983). Educational Research: an Introduction. Longman.

Dwianto, A, I., Wilujeng, K., Prasetyo, I. G. P., \& Suryadarma. (2017). Development of Science Domain Based Learning Media Tool Which is Integrated with Local Wisdom to Improve Science Process Skill and Scientific Attitude. Jurnal Pendidikan IPA 
$\begin{array}{llll}\text { Indonesia } & \text { (JPII), } & 6(1), & \text { 23-31. }\end{array}$

https://journal.unnes.ac.id/nju/index.php/jpii/article/view/7205/6320.

Elmubarok, Z. (2008). Membumikan Pendidikan Nilai. Alfabeta.

Enger, S. R., \& Yager, R. E. (2000). Assesing student understanding in science: $A$ standards-based K-12 handbook. Corwin Press.

Febriani, E. R., Sudarmin, S., \& Alimah, S. (2019). Local Wisdom Learning Approach Towards Students Learning Outcomes. Journal of Primary Education, 8(5), 197-205. https://journal.unnes.ac.id/sju/index.php/jpe/article/view/31352.

Hairida, H. (2016). The Effectiveness Using Inquiry Based Natural Science Module With Authentic Assessment to Improve The Critical Thinking and Inquiry Skills of Junior High School Students. Jurnal Pendidikan IPA Indonesia, 5(2). https://journal.unnes.ac.id/nju/index.php/jpii/article/view/7681/5453.

Harlen, W. (1992). The Teaching of Science. David Fulton Publishers.

Holbrook, J., \& Rannikmae, M. (2009). The Meaning of Scientific Literacy. International Journal of Environmental \& Science Education, 4(3), 275-288. https://files.eric.ed.gov/fulltext/EJ884397.pdf.

Ismail, K. H., Anwar, K., Energi, S., Selamat, J. H., \& Energi, A. (2013). Personality profile of students' council: A comparative study between genders. Asian Social Science, 9(4), 77. https://doi.org/10.5539/ass.v9n4p77.

Koesoema, A. (2009). Pendidikan Karakter di Zaman Keblinger Mengembangkan Visi Guru sebagai Pelaku Perubahan dan Pendidikan Karakter. PT Gramedia Widiasarana Indonesia.

Kristanto, A., Suharno, \& Gunarhadi. (2019). Promoting local wisdom in international primary curriculum aims to develop learners' problem solving skills. International Journal of Educational Research Review, 4(3), 439-447. https://doi.org/10.24331/ijere.573947.

Lickona. (1999). Character Education: Seven Crusial Issue. Action in Teacher Education, 20(4), 77-84. https://doi.org/10.1080/01626620.1999.10462937.

Loke, A. J. Y., \& Chow, F. L. (2007). Learning partnership-the experience of peer tutoring among nursing students: A qualitative study. Energi Journal of Nursing Studies, 44(2), 237-244. https://doi.org/10.1016/j.jinurstu.2005.11.028.

Lopes, J., Oliveira, C., Reed, L., \& Gable, R. A. (2013). Character Education in Portugal. Chilhood Education, 89(5), 286-289. https://doi.org/10.1080/00094056.2013.830880.

Mantiri, O. (2013). The Influence of culture on learning styles. SSRN. http://dx.doi.org/10.2139/ssrn.2566117.

Marhaeni, A. A. I. N., Dantes, N., \& Paramartha, A. A. G. Y. (2018). Teacher Assessment Literacy: Discrepancies in Authentic Assessment Practice in EFL Context. International Conference on Educational Assessment and Policy, 2, 18-21. https://doi.org/10.26499/iceap.v2i1.90.

Medwell, J., Wray, D., Minns, H., Coates, E., \& Griffiths, V. (2009). Primary English: Teaching Theory and Practice. Cromwell Press Group Ltd.

Mullis, I. V. S., Martin, M., \& Tom, L. (2016). 20 Years of TIMSS: International Trends in Mathematics and Science Achievement Curriculum and Instruction. International Association for the Evaluation of Educational Achievement (IEA).

Neka, I, K., Marhaeni, A. A. I. N., \& Suastra, I. W. (2015). Pengaruh Model Pembelajaran Inkuiri Terbimbing Berbasis Lingkungan Terhadap Keterampilan Berpikir Kreatif dan Penguasaan Konsep IPA Kelas V SD Gugus VIII Kecamatan Abang. E-Journal Program Pascasarjana Universitas Pendidikan Ganesha, 1, 1-11.

Neuby, B. (2010). Inquiry Teaching in the College Classroom. The Journal of Effective Teaching, 10(1), 4-21. https://files.eric.ed.gov/fulltext/EJ1092197.pdf.

Odell, B., Gierl, M., \& Cutumisu, M. (2021). Testing measurement invariance of PISA 2015 mathematics, science, and ICT scales using the alignment method. Studies in Educational Evaluation, 68. https://doi.org/10.1016/j.stueduc.2020.100965.

Priyantini, N. P. T., Sadia, I. ., \& Suastra, I. W. (2015). Pengembangan Perangkat Pembelajaran Fisika SMA Bermuatan Karakter dengan setting Model Sains Teknologi Masyarakat dan Lingkungan untuk Meningkatkan Karakter dan 
Keterampilan Berpikir Kreatif Siswa. Jurnal Pendidikan IPA, 5(1). https://ejournalpasca.undiksha.ac.id/index.php/jurnal_ipa/article/view/1568/1224.

Putri, A. S., \& Aznam, N. (2019). The effect of the science web module integrated on batik's local potential towards students' critical thinking and problem solving (thinking skill). Journal of Science Learning, 2(3), 92-96. https://doi.org/10.17509/jsl.v2i3.16843.

Samani, M., \& Hariyanto. (2012). Konsep dan Model Pendidikan Karakter. Remaja Rosdakarya.

Setiawan, B., Innatesari, D. K., Sabtiawan, W. B., \& Sudarmin, S. (2017). The development of local wisdom-based natural science module to improve science literation of students. Jurnal Pendidikan IPA Indonesia, 6(1), 49-54. https://doi.org/10.15294/jpii.v6i1.9595.

Suastra, I. . (2011). Pengembangan Karakter Bangsa Melalui Pendidikan Sains Berbasis Budaya Lokal. Undiksha Press.

Suastra, I. W. (2005). Merekonstruksi Sains Asli (Indigenous Science) dalam Rangka Mengembangkan Pendidikan Sains Berbasis Budaya Lokal di Sekolah. Jurnal Pendidikan Dan Pengajaran, 3(1), 377-396.

Suastra, I. W. (2010). Model Pembelajaran Sains Berbasis Budaya Lokal untuk Mengembangkan Kompetensi Dasar Sains dan Nilai Kearifan Lokal di SMP. Jurnal Pendidikan Dan Pengajaran, 43(1).

Suastra, I. W. (2017). Balinese Local Wisdoms and their Implications in Science Education at School. International Research Journal of Management, IT \& Social Sciences (IRJMIS), 4(2), 42 50. https://sloap.org/journals/index.php/irjmis/article/view/446.

Suastra, I. W., Jatmiko, B., Ristiati, N. P., \& Yasmini, L. P. B. (2017). Developing characters based on local wisdom of bali in teaching physics in senior high school. Jurnal Pendidikan IPA Indonesia, 6(2), 306-312. https://doi.org/10.15294/jpii.v6i2.10681.

Sudarmiani, S. (2013). Membangun Karakter Anak Dengan Budaya Kearifan Lokal Dalam Proses Pembelajaran Di Sekolah. EQUILIBRIUM: Jurnal IImiah Ekonomi Dan Pembelajarannya, 1(1), 54-72. https://doi.org/10.25273/equilibrium.v1i1.556.

Sugiyono. (2014). Metode Penelitian Pendidikan Pendekatan Kuantitatif, Kualitatif, dan R\&D. Alfabeta.

Sumaji. (1998). Pendidikan Sains yang Humanis. Kanisius.

Suryanti, S., Mariana, N., Yermiandhoko, Y., \& Widodo, W. (2020). Local wisdom-based teaching material for enhancing primary students' scientific literacy skill. Jurnal Prima Edukasia, 8(1), 96-105. https://journal.uny.ac.id/index.php/jpe/article/view/32898/pdf.

Van Joolingen, W. R., de Jong, T., Lazonder, A. W., Savelsbergh, E. R., \& Manlove, S. (2005). Co-Lab: research and development of an online learning environment for collaborative scientific discovery learning. Computers in Human Behavior, 21(4), 671-688. https://doi.org/10.1016/j.chb.2004.10.039.

Van Manen, M. (2016). Researching lived experience: Human science for an action sensitive pedagogy. Routledge.

Wenning, C. J. (2005). Level of Inquiry: Hirarchies of pedagogical practice and inquiry processes. Journal of Physic Teacher Education Online, 2(3), 3-11. https://doi.org/10.1.1.583.2818.

Zulfiani, Z., Suwarna, I. P., \& Sumantri, M. F. (2020). Science Adaptive Assessment Tool: Kolb's Learning Style Profile and Student's Higher Order Thinking Skill Level. Jurnal Pendidikan IPA Indonesia, 9(2), 194-207. https://doi.org/10.15294/jpii.v9i2.23840. 